Arq. Bras. Med. Vet. Zootec., v.73, n.6, p.1269-1277, 2021

\title{
Quantification of multi-oocyte follicles in ovaries of bitches
}

[Quantificação de folículos multiócitos em ovários de cadelas]

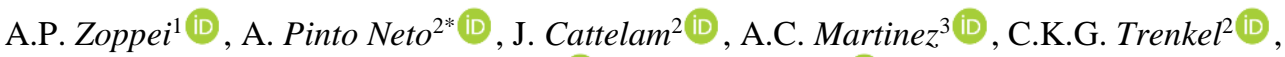 \\ R. Steffens ${ }^{4}$ (D) , L. Gruchouskei ${ }^{2}$ (D) \\ ${ }^{1}$ Practitioner, Chopinzinho, PR, Brasil \\ ${ }^{2}$ Universidade Federal da Fronteira Sul, Campus Realeza, Realeza, PR, Brasil \\ ${ }^{3}$ Universidade Estadual de Maringá, Campus Umuarama, Maringá, PR, Brasil \\ ${ }^{4}$ Practitioner, Toledo, PR, Brasil
}

\begin{abstract}
The objective of this study was to quantify the number and frequency of monocyte (MnOF) and multioocyte (MtOF) follicles in ovaries of bitches subjected to ovary salpingohysterectomy (OSH). Right and left ovaries of 38 bitches were collected after OSH, prepared, and a histological analysis was carried out. The ovaries were subjected to surface and deep histological cuts; the follicles were classified, and the number of follicles and cumulus oophorus complexes (COC) per follicle were quantified for each histological cut. MnOF and MtOF were found in all ovaries, at different developmental stages; primary follicles were grouped in the ovarian cortex, and follicles at other follicular stages presented a random distribution. MtOF containing two, three, four, or more COC were found in the ovaries of bitches, with a decreasing frequency trend, according to the number of $\mathrm{COC}$ in the MtOF. The effect of the age, number of estrus, estrus interval, and number of progenies per delivery was not significant for the number and frequency of MtOF in the ovaries of the bitches, whereas the size, number of pregnancies, use and number of contraceptive applications had some effect on the number and frequency of MtOF in the ovaries of the bitches.
\end{abstract}

Keywords: reproduction, cyclicality, multi-oocytes

\section{RESUMO}

Objetivou-se, com este estudo, quantificar o número e a frequência de folículos monocitários (MOF) e polioocitários $(\mathrm{POF})$ provenientes de ovários de cadelas submetidas à ovariossalpingo-histerectomia (OSH). Para tanto, coletaram-se os ovários (direito e esquerdo) de 38 cadelas após OSH, com posterior preparação e análise histológica. Cada ovário foi submetido a dois cortes histológicos (superficial e profundo) onde se quantificou o número e a classificação dos folículos, bem como o número de complexos cumulus oophorus (COCs) por folículo em cada corte histológico. Observaram-se MOF e POF em todos os ovários estudados, em diferentes estádios de desenvolvimento, sendo os folículos primários agrupados no córtex ovariano, frente a uma distribuição aleatória dos outros estádios foliculares. FOPs contendo dois, três, quatro ou mais COCs foram observados nos ovários de todas as fêmeas estudadas, e sua frequência tendeu a diminuir de acordo com o número de COC presente no POF. Não se observou influência da idade, do número e do intervalo de estros, assim como do número de filhotes por gestação sobre o número/frequência de FOP nos ovários das cadelas estudadas, enquanto o porte, o número de gestações, o uso e o número de contraceptivo apresentaram algum grau de influência sobre o número/frequência de FOP nos ovários das cadelas estudadas.

Palavras-chave: reprodução, ciclicidade, multioócitos

*Corresponding author: adalgiza.uffs@gmail.com

Submitted: April 14, 2021. Accepted: July 15, 2021 


\section{INTRODUCTION}

Bitches are monoestrous, poliovulatory, nonseasonal animals, with a different reproductive cycle from other domestic animal species; they present high bloody progesterone concentrations in days preceding the ovulation, and oocytes ovulated at the immature diploid stage that finish their mitotic maturation in the uterine tubes, where they survive for several days (Rôlo, 2012).

In addition, unlike other mammals, the oocyte production period by oogonia or primordial germ cells (oogenesis) in bitches occur up to two months after birth since proliferation cells are found in the ovary cortical region. The lipid granules increase during the canine oogenesis process, resulting in oocytes with dark appearance, which does not occur in other mammals (Derussi and Lopes, 2009).

Folliculogenesis in bitches has high occurrence of polyovular follicles, with higher occurrences in young bitches, which decreasing during their senescence (Rôlo, 2012). Bysted et al. (2001) and Reynaud et al. (2005) reported that multi-oocyte follicles can also ovulate, releasing oocytes morphologically different from each other, because of unknown causes, which can be related to high pre-ovulatory follicle density in the ovarian cortex of young animals (Derussi and Lopes, 2009).

Despite the origin of these multi-oocyte follicles still being unknown, it can be associated to flaws in germinative cell degradation or the folliculogenesis initial stages, in which the developmental rate is faster than the differentiation of the surrounding somatic cells (Payan-Carreira and Pires, 2008).

In this context, the objective of this study was to quantify the number and frequency of monocytes (MnOF) and multi-oocyte (MtOF) follicles from ovaries of bitches subjected to ovary salpingohysterectomy (OSH).

\section{MATERIAL AND METHODS}

The procedures used in this study were approved by the Animal Ethics Committee (CEUA) of Universidade Federal da Fronteira Sul (UFFS; Protocol no. 23205.001819/2018-21). Ovaries of 38 bitches were subjected to OSH to collect data regarding age, weight, size, number of estrus, estrus interval, number of pregnancies, number of progenies per delivery, and use and number of applications of contraceptive.

The criterion used to determine the animal size was based on the study of Klein (2012). After surgical removal of the ovaries, they were identified as right or left, subjected to a longitudinal cut, and stored in a $10 \%$ formalin solution for tissue fixation and histological preparation (dehydration, inclusion, cut, and staining with hematoxylin-eosin) (Junqueira and Carneiro, 2013). They were embedded in paraffin and two consecutive microtome cuts distant 60 micrometers from each other, termed as surface and deep cuts, were carried out. After they were fixed, the slides were stained with hematoxylineosin, following the procedure used by Timm (2005).

The slides were analyzed using an optical microscope coupled to a camera (Olympus CX33) to capture the images. A complete screening was carried out for each cut of the ovarian tissue, enabling the quantification (10x objective) and classification (40x objective) of primary, secondary, and tertiary follicles, and the number of cumulus oophorus complexes (COC) per follicle, classifying them as $\mathrm{MnOF}$ (with one $\mathrm{COC}$ ) or MtOF (with two, three, or more COC).

The data were collected and the follicles in the surface and deep histological cuts were evaluated, considering the mean and standard deviation of the number of primary, secondary and tertiary $\mathrm{MnOF}$ in the right and left ovaries, the number and occurrence (\%) of MtOF in the right and left ovaries, and the number and occurrence of MtOF in the ovaries of the bitches, according to their age, size, estrus interval, number of pregnancies, number of progeny, and use and number of contraceptive applications.

The data were tabbed in electronic spreadsheets in the Microsoft Excel ${ }^{\circledR}$ program, and the statistical analyses were processed in the SAS.

\section{RESULTS AND DISCUSSION}

The characteristics of the bitches subjected to OSH for age, weight, number of estrus, estrus interval, number of pregnancies, number of progenies per delivery, and number and use of contraceptive applications are shown in Table 1. 
Quantification of multi-oocyte...

Table 1. Characteristics of bitches subjected to OSH for evaluation of ovarian follicles.

\begin{tabular}{lcc}
\hline \multicolumn{1}{c}{ Variable } & Variation & Mean \pm Standard deviation \\
\hline Age (months) & $6-132$ & $38.0 \pm 37.0$ \\
Weight (kg) & $1.35-24.9$ & $8.67 \pm 6.00$ \\
Number of estrus & $0-11$ & $2.8 \pm 3.1$ \\
Estrus interval (months) & $4-48$ & $6.9 \pm 8.6$ \\
Number of pregnancies & $0-3$ & $0.63 \pm 0.88$ \\
Number of progenies per delivery & $1-8$ & $1.8 \pm 2.4$ \\
Use contraceptive applications & $0-6$ & $0.5 \pm 1.2$ \\
\hline
\end{tabular}

Figure 2 shows the ovarian histological cut containing $\mathrm{MnOF}$ at different developmental stages. Ovarian follicular population is heterogeneous, and the follicles can be divided into preantral follicles according to the developmental stage, consisting in primordial, primary, and secondary follicles, which correspond to $90 \%$ of the ovarian follicular population; and preantral follicles, tertiary and Graaf follicles, also called pre-ovulatory follicles (Serafim, 2009).
The MnOF were classified considering follicles with a single cuboidal granulosum cell layer as primary (Figure 2C); follicles with more than a granulosum cell layer, with a well-defined translucent zone involving the oocyte, as secondary (Figure 3B); and follicles with several granulosum cell layer and theca cells with established antral cavity as tertiary (Figure 2A). Follicular classification in bitches was also described by Van Den Hurk and Zhao (2005), Almeida et al. (2015), Zertlotini (2016), and Cardoso (2017).

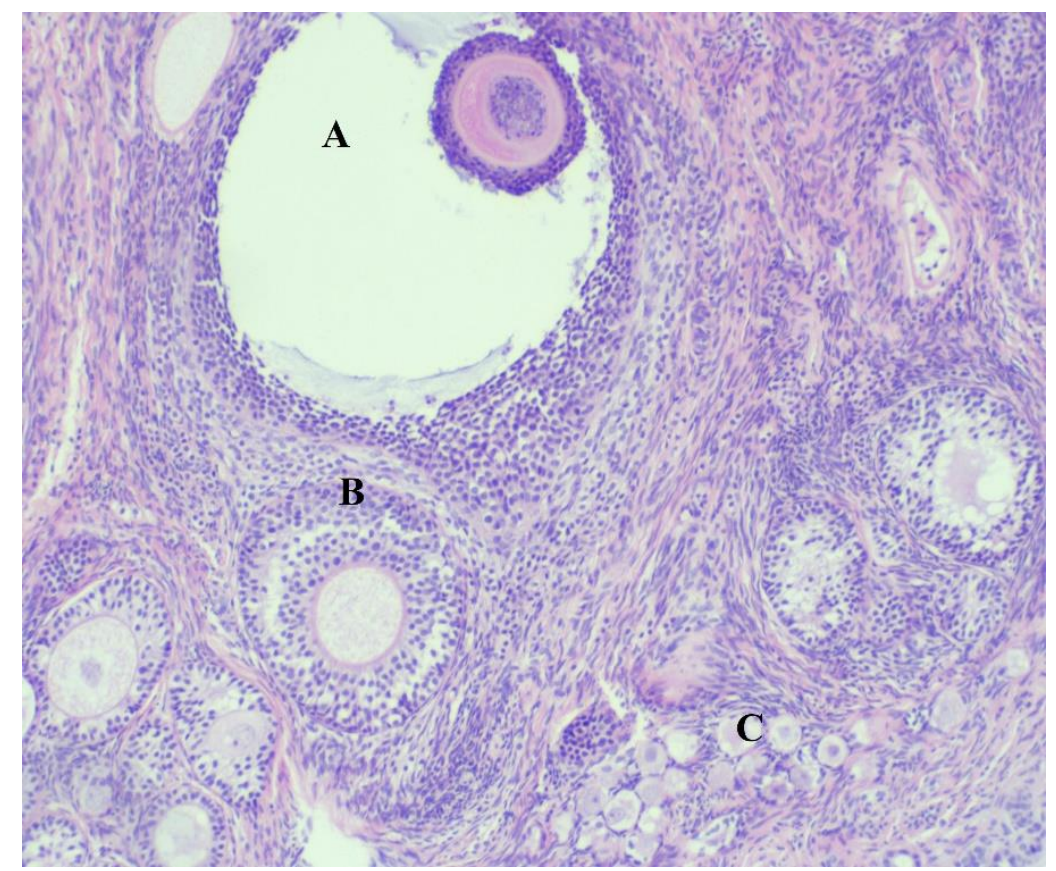

A: Tertiary MnOF; B: Secondary MnOF; C: Primary MnOF grouped in clusters.

Figure 2. Histological cut in an ovary of a bitch containing monocyte (MnOF) follicles at different developmental stages (40x objective).

A group of primary follicles was found in in the ovary cortical regions, in clustering (Figure 2C) or cord shapes, whereas those at other developmental stages were randomly distributed in the ovarian cortex, as also described by McDougall et al. (1997). A large quantity of fibrous tissue and bloody vessels, with absence of follicles, was found in the medullary region, 
confirming the findings of Telfer and Gosden (1987)

The means found for primary, secondary, and tertiary $\mathrm{MnOF}$ in the right and left ovaries were similar $(p>0.05)$ (Table 2). However, Lunardon et al. (2015) reported differences in number of follicles between right and left ovaries from the same bitch, and in other established groups of bitches; they concluded that the evaluation of only one histological cut per ovary can underestimate or overestimate the follicle population.

Table 2. Presence and classification of monocyte follicle (MnOF) (mean \pm standard deviation) in ovaries of bitches

\begin{tabular}{ccc}
\hline MnOF & Right Ovary & Left Ovary \\
\hline Primary & $146.5 \pm 11.4^{\mathrm{a}}$ & $137.3 \pm 11.4^{\mathrm{a}}$ \\
Secondary & $17.5 \pm 1.7^{\mathrm{b}}$ & $15.5 \pm 1.7^{\mathrm{b}}$ \\
Tertiary & $2.6 \pm 0.3^{\mathrm{c}}$ & $2.5 \pm 0.3^{\mathrm{c}}$ \\
\hline
\end{tabular}

$\overline{\text { abc }}$ Means followed by different letters in columns are different $(p<0.05)$.

The number of primary follicles was higher than the number of secondary and tertiary follicles $(p<0.05)$; and the number of secondary follicles was higher than the number of tertiary follicles $(p<0.05)$ (Table 2). Similar results were found by Telfer and Gosden (1987) and Dolezel et al. (2004), who reported higher occurrence of primary and secondary than tertiary follicles in ovaries of bitches. This can be associated to the higher predominance of primordial, primary, and secondary follicles in the ovarian follicular population, which corresponds to approximately 90\% of them (Serafim, 2009).

Lunardon et al. (2015) reported predominance of primordial follicles (92.2\%) in ovaries of bitches and reported that this was also found for other species, such as bovine. The higher quantity of primordial follicles in the ovary explains the use of these follicles in assisted reproduction methods, and the difficult in in vitro oocyte maturation since primordial follicles require more time and developmental factors to reach the maturation stage.

The occurrence of MtOF which presented two to four, or more COC per follicles (Table 3) was consistent with the descriptions of ChastantMaillard et al. (2011) that 4\% of pre-ovulatory follicles can be MtOF, containing two to five COC. Similarly, Payan-Carreira and Pires (2008) reported that more than one MtOF may be in the same histological cut, as found in the present study (Figure 3).

Table 3. Mean number (MN) and frequency (MF) of follicles in right and left ovaries of bitches subjected to elective OSH, containing one, two, three, or four, or more cumulus oophorus complexes (COC)

\begin{tabular}{ccccccccc}
\hline \multirow{2}{*}{ Ovary } & \multicolumn{7}{c}{ Number of COC in the follicles } \\
\cline { 2 - 9 } & \multicolumn{2}{c}{ One } & \multicolumn{2}{c}{ Two } & \multicolumn{2}{c}{ Three } & \multicolumn{2}{c}{ Four or more } \\
\cline { 2 - 9 } & MN & MF & MN & MF & MN & MF & MN & MF \\
\hline Right & 162.2 & 100.0 & 3.0 & 68.0 & 0.63 & 30.7 & 0.05 & 16.7 \\
Left & 151.7 & 100.0 & 2.6 & 60.0 & 0.54 & 25.6 & 0.04 & 10.2 \\
\hline
\end{tabular}




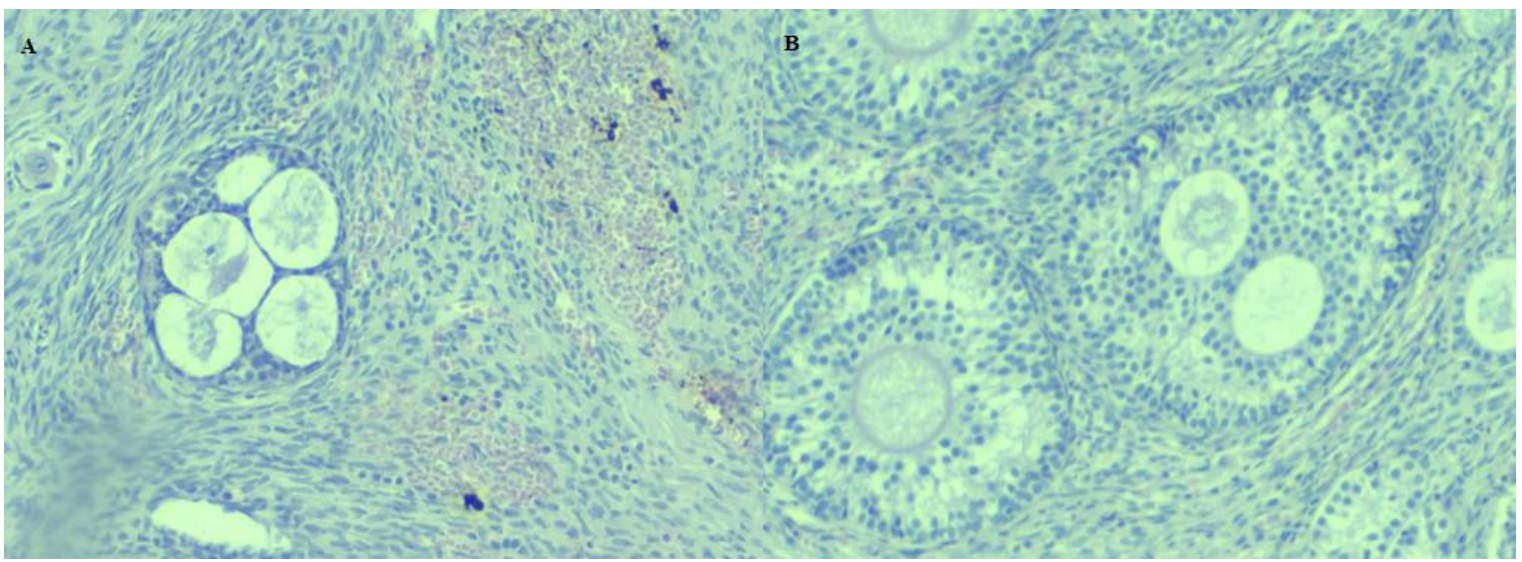

A: Secondary MtOF with five COC; B: secondary MtOF with two COC.

Figure 3. Histological cut of an ovary of a bitch containing multi-oocyte follicles (MtOF) (40x objective).

The occurrence of follicles containing one to four, or more COC was found in all ovaries (Table 3). The number and frequency of this occurrence was similar between right and left ovaries $(p>0.05)$, presenting similar MnOF and MtOF values (Table 3). Similarly, Payan-Carreira and Pires (2008) reported bilateral occurrence of MtOF in ovaries of bitches, with $18 \%$ and $37.7 \%$ for pre-pubescent and mature bitches, respectively.

However, the number and frequency of MnOF was higher than that of MtOF containing two COC, followed by MtOF containing three, and four, or more COC $(p<0.05)$. Telfen and Gosden (1987) found similar results, with predominance of MnOF in ovaries of bitches, followed by follicles containing two COC. Payan-Carreira and Pires (2008) reported that the occurrence of $\mathrm{MnOF}$ is more expressive in bitches. However, Telfer and Gosden (1987) reported that MnOF is prevalent in the ovarian tissue of in all species, and findings of MtOF are specific and misunderstood functional characteristics of some species, including canine species. Similar results were found in the present study, with MnOF population larger than the MtOF population (Table 3).

The COC morphology varied within the same MtOF, showing that these COC were probably at different developmental stages (Figure 4), as described by Payan-Carreira and Pires (2008).

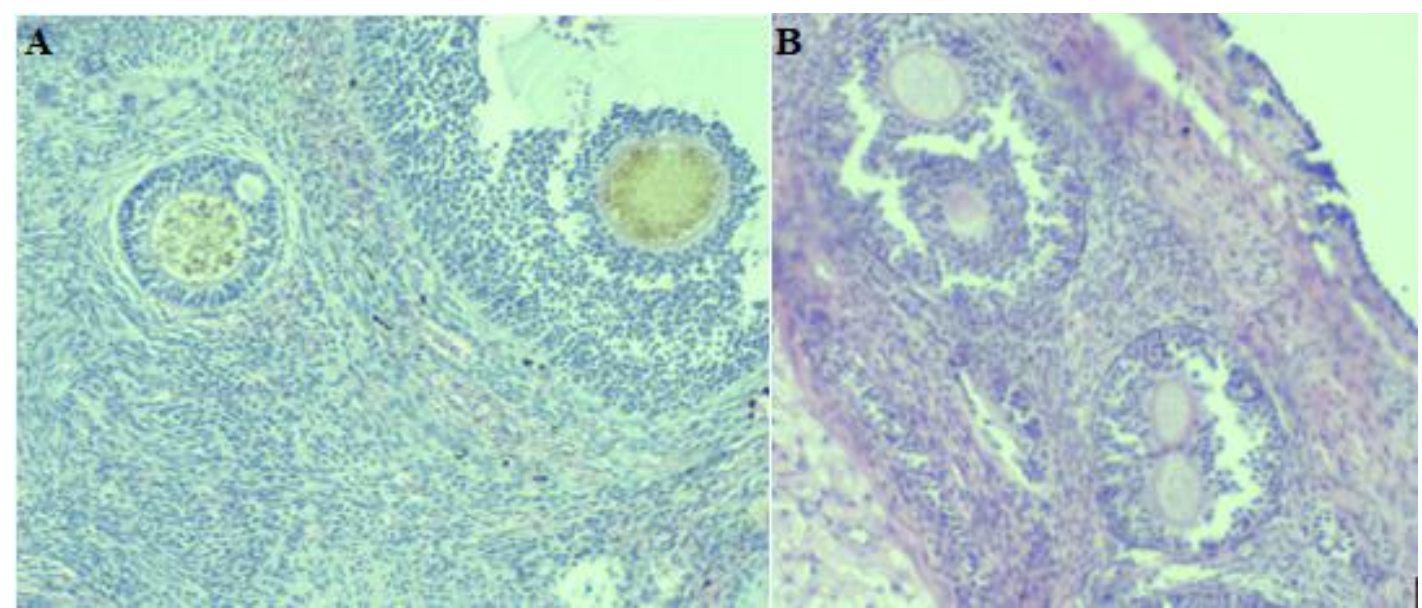

A: secondary monocyte follicles with oocytes at different developmental stages;

B: secondary multi-oocyte follicles with oocytes at different developmental stages.

Figure 4. Histological cut of ovary of bitches containing follicles with oocytes at different developmental stages. 
Reynaud et al. (2009) found differences in developmental stages in MtOF, identified by variations in the cytoplasmic color, functional mucification of the cumulus, and nuclear aspects that show different morphological characteristics between the oocytes of a same follicle. Moreover, MtOF may present two- to three-fold more volume than $\mathrm{MnOF}$ at the same developmental stage, which is attributed to the higher number of oocytes and granulosum cells in them. In addition, Silva-Santos and Seneda (2011) pointed out that the smaller oocyte of the MtOF may undergo a developmental delay that triggers its degeneration.

According to Chastant-Maillard et al. (2011), in vitro studies of these oocytes is necessary to evaluate their maturation and fertilization capacity, since when the follicle is ovulated, all oocytes that are captured by the fimbriae of the uterine tubes can or not be fertilized. Thus, in addition to the variations in size between MnOF and $\mathrm{MtOF}$, they may present oocytes with different maturity and quality (Silva-Santos and
Senada, 2011). Oliveira et al. (2017) working with bovine oocytes from multi-oocyte follicles found that these follicles may be at different cell stages or have a certain oocyte dominance, and this may be a factor in decreasing fertility.Unlike other mammals, bitches ovulate oocytes at prophase I and are dependent on the LH peak for mucification and maturation of oocytes before ovulation. This has been questioned for this species, since their LH peak varies from 24 to 72 hours, and a delay between the LH peak and the ovulation varies from 36 to 50 hours, which can make it unfeasible, mainly for oocytes with delayed developmental stages (De Gier et al., 2005).

The age had no effect on the occurrence of MtOF containing two, three, four, or more $\mathrm{COC}$ $(p<0.05)$, However, the number of COC per MtOF was numerically less expressive in animals of the same age (Table 4). Older bitches presented a smaller follicular population than the younger ones.

Table 4. Mean number (MN) and frequency (MF) of Monocyte Follicle (MnOF) and Multi-oocyte follicles (MtOF) in ovaries of bitches of different ages

\begin{tabular}{ccccccccc}
\hline \multirow{2}{*}{$\begin{array}{c}\text { Age } \\
\text { (months) }\end{array}$} & \multicolumn{9}{c}{ Number of COC in the follicles } \\
\cline { 2 - 10 } & \multicolumn{2}{c}{ One } & \multicolumn{2}{c}{ Two } & \multicolumn{2}{c}{ Three } & \multicolumn{2}{c}{ Four or more } \\
\cline { 2 - 10 } & MN & MF & MN & MF & MN & MF & MN & MF \\
\hline 12 & 181.2 & 100.0 & 3.5 & 87.5 & 0.97 & 75.0 & 0.09 & 50.0 \\
$12-24$ & 178.3 & 100.0 & 2.8 & 100.0 & 0.31 & 50.0 & 0.02 & 12.5 \\
$25-36$ & 154.4 & 100.0 & 4.5 & 100.0 & 1.00 & 33.3 & 0.06 & 33.3 \\
$>36$ & 101.2 & 100.0 & 3.3 & 50.0 & 0.62 & 50.0 & 0.06 & 50.0 \\
\hline
\end{tabular}

Chastant-Maillard et al. (2011) and PayanCarreira and Pires (2008) reported higher quantity of MtOF in young bitches, which decreased over time due to the senescence. Similarly, Farstad (2000) and Rocha et al. (2006). Binsfeld et al. (2014) reported that young bitches presented higher MtOF indexes than old ones, since adult bitches with ages lower than seven years have larger follicular population and higher number of high-quality oocytes than young or senescent ones. This is consistent with the findings of Steckler et al. (2017), who reported occurrence of only $1 \%$ of MtOF in young bitches at anestrus and none multi-oocyte follicle in senescent bitches.

Payan-Carreira and Pires (2008) reported a mean frequency of MtOF of $68.4 \%$ in pre- pubescent animals and $30.4 \%$ in senescent animals (above seven years of age). The mean age of bitches in the present study was 37.0 to 38.0 months, and pre-pubescent and adult bitches presented no difference in frequency of MtOF (Table 4).

Bitches of medium size presented higher $(p<0.05)$ mean number of MtOF containing three $\mathrm{COC}$ than those of small or very small sizes (Table 5). The bitch sizes had no effect $(p>0.05)$ on the number of MtOF containing two, four, or more COC (Table 5). Similar results were found by Lunardon et al. (2015), who reported larger follicular population and prevalence of MtOF in mediumsize bitches, when compared to small-size ones. 
Table 5. Mean number (MN) and frequency (MF) of Monocyte Follicle (MnOF) and Multi-oocyte follicles (MtOF) in the ovaries of bitches with different sizes

\begin{tabular}{ccccccccc}
\hline \multirow{2}{*}{ Size } & \multicolumn{7}{c}{ Number of COC in the follicles } \\
\cline { 2 - 9 } & \multicolumn{2}{c}{ One } & \multicolumn{2}{c}{ Two } & \multicolumn{2}{c}{ Three } & \multicolumn{2}{c}{ Four or more } \\
\cline { 2 - 9 } & MN & MF & MN & MF & MN & MF & MN & MF \\
\hline Very small & 160.0 & 100.0 & 3.2 & 90.0 & $0.57^{\mathrm{B}}$ & 60.0 & 0.07 & 40.8 \\
Small & 146.3 & 100.0 & 2.5 & 80.0 & $0.42^{\mathrm{B}}$ & 50.0 & 0.02 & 20.0 \\
Medium & 224.0 & 100.0 & 6.5 & 100.0 & $1.91^{\mathrm{A}}$ & 66.7 & 0.12 & 66.7 \\
\hline
\end{tabular}

$\mathrm{AB}$ Means followed by different letters in columns are different $(p<0.05)$.

The estrus cycle frequency of bitches varies; and their estrus interval can be affected by some factors, such as heredity, race, pregnancy, and age of the bitches. Oliveira and Marques Jr (2006) found higher estrus interval in senescent bitches, which presented a light, but progressive increases in inter-estrus interval up to four years of age; and after seven years of age the occurrence of irregularities in the cycle estrus is shown with long anestrus periods, followed by increases in estrus intervals.

The mean of number of estrus (up to four, five to seven, and more than eight) and the estrus interval (up to six, and more than seven months) of the bitches evaluated were 2.8 to 3.1 , and 6.9 to 8.6 , respectively. However, the number of estrus and the estrus interval had no effect on the mean number and frequency of MtOF with two, three, four, or more COC ( $p<0.05)$. Payan-Carreira and Pires (2008) showed that the occurrence of MtOF is affected by the reproductive stage of the bitches, in pre-pubescent and pubescent, with higher incidence in pre-pubescent animals.

The number of pregnancies affected the frequency of $\mathrm{MtOF}$ in the ovaries of the bitches $(p<0.05)$ (Table 6), showing higher frequency of MtOF with up to three COC in bitches that had no pregnancy $(p<0.05)$, and higher frequency of $\mathrm{MtOF}$ with four or more COC in bitches with at least one pregnancy $(p<0.05)$.

Table 6. Mean number (MN) and frequency (MF) of Monocyte Follicle (MnOF) and Multi-oocyte follicles (MtOF) in ovaries of bitches with different number of pregnancies

\begin{tabular}{ccccccccc}
\hline \multirow{2}{*}{$\begin{array}{c}\text { Number of } \\
\text { Pregnancies }\end{array}$} & \multicolumn{9}{c}{ Number of COC in the follicles } \\
\cline { 2 - 9 } & \multicolumn{2}{c}{ One } & \multicolumn{2}{c}{ Two } & \multicolumn{2}{c}{ Three } & \multicolumn{2}{c}{ Four or more } \\
\cline { 2 - 9 } & MN & MF & MN & MF & MN & MF & MN & MF \\
\hline None & 161.8 & 100.0 & 3.1 & 86.7 & 0.70 & $66.7^{\mathrm{A}}$ & 0.07 & $40.0^{\mathrm{A}}$ \\
One & 149.5 & 100.0 & 4.6 & 83.3 & 0.87 & $50.0^{\mathrm{A}}$ & 0.04 & $33.3^{\mathrm{A}}$ \\
Two or more & 209.7 & 100.0 & 1.3 & 100.0 & 0.00 & $0.00^{\mathrm{B}}$ & 0.00 & $0.00^{\mathrm{B}}$ \\
\hline
\end{tabular}

$\overline{\mathrm{AB}}$ Means followed by different letters in columns are different $(p<0.05)$.

The number of progenies per delivery (one to two, three to four, or more) of bitches had no effect on the mean number and frequency of $\mathrm{MtOF}$ $(p<0.05)$. The bitches showed precocious sexual maturity, six months of age; this reproductive characteristic enables the increase of dog population (Bueno and Rédua, 2020). Thus, the indiscriminate use of contraceptive applications is evident, which efficiently blocked the cyclicality of the bitches, but originated several collateral effects. The main uterine affections and pregnancy and delivery disturbances in bitches are due to exogenous hormonal manipulation through contraceptive applications (Aguirra, 2013). Chaves et al. (2021) reported that ewe that have the $\mathrm{FecG}^{\mathrm{E}}$ gene, a gene associated with sheep fertility, do not have a higher proportion of multioocyte follicles. But the mutant ewes had a greater frequency of morphologically normal multioocyte follicles, this may justify the better prolificity of these ewes.

However, despite the harmful effects of contraceptive applications in canine females, a higher $(p<0.05)$ frequency of MtOF containing two COC was found in bitches that had not received contraceptive applications (Table 7). However, the use of contraceptive applications had no effect $(p>0.05)$ on the mean number and frequency of MtOF containing three, four, or more COC (Table 7). 
Table 7. Mean number (MN) and frequency (MF) of Monocyte Follicle (MnOF) and Multi-oocyte follicles (MtOF) in ovaries of bitches with and without use of contraceptive applications

\begin{tabular}{ccccccccc}
\hline \multirow{2}{*}{$\begin{array}{c}\text { Use of } \\
\text { contraceptive }\end{array}$} & \multicolumn{7}{c}{ Number of COC in the follicles } \\
\cline { 2 - 10 } & \multicolumn{2}{c}{ One } & \multicolumn{2}{c}{ Two } & \multicolumn{2}{c}{ Three } & \multicolumn{2}{c}{ Four or more } \\
\cline { 2 - 10 } & MN & MF & MN & MF & MN & MF & MN & MF \\
yes & 93.2 & 100.0 & 3.16 & $33.3^{\mathrm{B}}$ & 0.25 & 33.3 & 0.06 & 33.3 \\
no & 173.2 & 100.0 & 3.36 & $95.0^{\mathrm{A}}$ & 0.75 & 60.0 & 0.05 & 35.0 \\
\hline
\end{tabular}

${ }_{\mathrm{AB}}$ Means followed by different letters in columns are different $(p<0.05)$.

The number of contraceptive applications affected $(p<0.05)$ the frequency of MtOF in the bitches (Table 8). Bitches that received one contraceptive application presented higher $(p<0.05)$ frequency of MtOF containing two, three, four, or more COC than those had received more than two applications, which presented no MtOF (Table 8).
Contrastingly, according to Silva-Santos and Seneda (2011), the occurrence of multi-oocyte follicles is not affected when using gonadotropic hormones and/or contraceptive methods, which contrasts with the results found in the present study.

Table 8. Mean number (MN) and frequency (MF) of Monocyte Follicle (MnOF) and Multi-oocyte follicles (MtOF) in ovaries of bitches with zero, one, or two or more contraceptive applications

\begin{tabular}{ccccccccc}
\hline \multirow{2}{*}{$\begin{array}{c}\text { Number of } \\
\text { contraceptive } \\
\text { applications }\end{array}$} & \multicolumn{9}{c}{ One } & \multicolumn{2}{c}{ Two } & \multicolumn{2}{c}{ Three } & Four or more \\
\cline { 2 - 9 } & MN & MF & MN & MF & MN & MF & MN & MF \\
\hline Zero & 173.2 & 100.0 & $3.36^{\mathrm{AB}}$ & 95.0 & 0.75 & $60.0^{\mathrm{A}}$ & 0.05 & $35.0^{\mathrm{A}}$ \\
One & 150.8 & 100.0 & $9.5^{\mathrm{A}}$ & 100.0 & 0.75 & $100.0^{\mathrm{A}}$ & 0.18 & $100.0^{\mathrm{A}}$ \\
Two or More & 64.5 & 100.0 & $0.00^{\mathrm{B}}$ & 0.00 & 0.00 & $0.00^{\mathrm{B}}$ & 0.00 & $0.00^{\mathrm{B}}$ \\
\hline
\end{tabular}

$\overline{\mathrm{AB}}$ Means followed by different letters in columns are different $(p<0.05)$.

\section{CONCLUSIONS}

Under the conditions of the present study, the bitches presented multi-oocyte follicles in all ovaries, at different developmental stages and frequency, without direct correlation with age and cyclicality.

\section{REFERENCES}

AGUIRRA, L.R.V.M. Alterações anatomopatológicas ovarianas e uterinas de cadelas e gatas domiciliadas na região metropolitana de Belém, Pará. 2013. Dissertação (Mestrado em Saúde e Produção Animal) Universidade Federal Rural da Amazônia, Belém, PA.

ALMEIDA, M.V.D.; CASTRO, D.S.; RIAL, L.C. et al. Identificação imuno-histoquímica de VEGF e IGF-1 em ovários de cadelas no anestro e estro. Arq. Bras. Med. Vet. Zootec., v.67, p.334-342, 2015.

BINSFELD, L.C.; DARRIBA, R.V.; BORGES, J.L. et al. Avaliação ovariana morfométrica e recuperação de complexos cumulus oophorus de cadelas em diferentes fases do ciclo estral. Arch. Vet. Sci., v.19, p.31-39, 2014.
BUENO, L.C.V.; RÉDUA, C.R.O. Uso e consequências dos principais métodos contraceptivos em cadelas na região do Distrito Federal. Rev. Ciênc. Saúde Anim., v.2, p.1-13, 2020.

BYSTED, B.V.; DIELEMAN, S.J.; HYTTEL, P. et al. Embryonic developmental stages in relation to the $\mathrm{LH}$ peak in dogs. J. Reprod. Fertil., v.57, p.181-186, 2001.

CARDOSO, C.F.R. Desenvolvimento folicular ao longo do ciclo éstrico na cadela e gata. 2017. Dissertação (Mestrado em Medicina Veterinária) Universidade Lusófona de Humanidade e Tecnologia, Lisboa, POR.

CHASTANT-MAILLARD， S.; LESEGNO, C.V.; CHEBROUT, M. et al. The canine oocyte: uncommon features of in vivo and in vitro maturation. Reprod. Fertil. Dev., v.23, p.391-402, 2011.

CHAVES, M.S.; AZEVEDO, H.C.; LUZ, V.B. et al. Occurrence, morphology, and morphometry of follicles containing multiple oocytes in $\mathrm{FecG}^{\mathrm{E}}$ mutant Santa Ines ewes. Anim. Reprod. Sci., v.226, p.106690, 2021.

DE GIER, J.; KPPISTRA, H.S.; DJAJADININGRATLAANEN, S.C. et al. Temporal relations between plasma concentrations of luteinizing hormone, folliclestimulating hormone, estradiol-17beta, progesterone, prolactin, and alpha-melanocyte-stimulating hormone during the follicular, ovulatory, and early luteal phase in the bitch. Theriogenology, v.65, p.1346-1359, 2005. 
DERUSSI, A.A.P.; LOPES, M.D. Fisiologia da ovulação, da fertilização e do desenvolvimento embrionário inicial na cadela. Rev. Bras. Reprod. Anim., v.33, p.231-237, 2009.

DOLEZEL, R.; KYLIANKOVA, R.; KUMMER, V. et al. Follicular population and oestrogen receptor alpha in ovary of the bitch. Acta Sci. Vet., v.73, p.37-43, 2004.

FARSTAD, W. Assisted reproductive technology in canid specie. Theriogenology, v.53, p.175-186, 2000.

JUNQUEIRA, L.C.; CARNEIRO, J. Aparelho reprodutor feminino. In: __ (Eds.). Histologia básica. 12.ed. Rio de Janeiro: Guanabara Koogan, 2013. p.427-446.

KLEIN, M. Dispensador de brinquedos para cães. 2012. 193f. Trabalho de Conclusão de Curso (Graduação Design de Produtos) - Universidade Federal do Rio Grande do Sul, Porto Alegre, RS.

LUNARDON, N.T.; SILVA-SANTOS, K.C.; JUSTINO, R.C. et al. Population estimate of the preantral follicles and frequency of multioocyte follicles in prepubertal and adult bitches. Theriogenology, v.83, p.1015-1020, 2015.

MCDOUGALL, K.; HAY, M.A. GOODROWE, K.L. et al. Changes in the number of follicles and of oocyte in ovaries of prepubertal and mature bitches. J. Reprod. Fertil. Suppl., v.51, p.24-31, 1997.

OLIVEIRA, E.C.S.; MARQUE JUNIOR, A.P. Endocrinologia reprodutiva e controle da fertilidade da cadela. Rev. Bras. Reprod. Anim., v.30, p.11-18, 2006.

OLIVEIRA, R.L.; SILVA-SANTOS, K.C.; MIGUEZ GONZÁLEZ, S. et al. Proliferative activity of oocytes in multi-oocyte follicles of bovine ovary. Semin. Ciênc. Agrár., v. 38, p.3591-3597, 2017

PAYAN-CARREIRA, R.; PIRES, M.A. Multioocyte in domestic dogs: a survery of frequency of occurrence. Theriogenology, v.69, p.977-982, 2008.

REYNAUD, K.; FONTBONNE, A.; MARSELOO, N. et al. In vivo meiotic resumption, fertilization and early embryonic development in the bitch. J. Soc. Reprod. Fertil., v.130, p.193-201, 2005.
REYNAUD, K.; LESENGO, C.V.; CHEBROUT, M. et al. Follicle population, cumulus mucification, and oocyte chromatin configuration during the periovulatory period in the female dog. Theriogenology, v.72, p.1120-1131, 2009.

ROCHA, A.A.; BASTOS, R.; CUNHA, I.C.N. et al. Quantity and quality of oocytes recovered from donor bitches of different ages. Theriogenology, v.66, p.14651467, 2006.

RÔLO, J.L.J. Estudo da população e criopreservação de folículos ovarianos pré-antrais de cadelas. 2012. 70f. Dissertação (Mestrado em Medicina Veterinária) Universidade de Brasília, DF.

SERAFIM, MKB. Cultivo de folículos pré-antrais caninos em diferentes concentrações de hormônio folículo estimulante. 2009. 56f. Dissertação (Programa de Pós-Graduação em Ciências Veterinárias) Universidade Estadual do Ceará, CE.

SILVA-SANTOS, K.C.; SENEDA, M.M. Multioocyte follicles in adult mammalian ovaries. Anim. Reprod., v.8, p.58-67, 2011.

STECKLER, D.; CRAMER, K.G.M.; NOTHLING, J.O. Estimated impact of multiple conceptuses per follicle on fecundity in the bitch. Theriogenology, v.102, p.108-115, 2017.

TELFER, E.; GOSDEN, R.G. A quantitative cytological study of polyovular follicles in mammalian ovaries with particular reference to the domestic bitch (Canis familiaris). J. Soc. Reprod. Fertil., v.81, p.137147, 1987.

TIMM, L.L. Técnicas rotineiras de preparação e análise de lâminas histológicas. Cad. Salle 11., v.2, p.231-239, 2005.

VAN DEN HURK, R.; ZHAO, J. Formation of mammalian oocytes and their growth, differentiation and maturation within ovarian follicles. Theriogenology, v.63, p.1717-1751, 2005.

ZERLOTINI, M.F. Desenvolvimento folicular em fragmentos ovarianos de cadelas (canis lupus familiaris) cultivados em meios "MEM" suplementado como soro de cadela no proestro e cadela gestante. 2016. 51f. Dissertação (Pós-Graduação em Medicina Veterinária para obtenção do título Magister Scientiae) - Universidade Federal de Viçosa, Viçosa, MG. 